THOMAS STUART

\title{
The Protection of Journalists' Sources in New Zealand and Australia
}

Submitted for the LLB (Honours) Degree

Faculty of Law

Victoria University of Wellington

2014 


\section{Abstract}

The degree of legal protection given to journalists' sources in New Zealand and Australia has progressed considerably over the last 30 years. Both nations have moved from a landscape of virtually no source protection to a strong presumption against source disclosure. This paper examines the history of this progression, its merits and its shortcomings. It highlights a distinct 'Australasian approach' to source protection and assesses this approach against other domestic and international methods in order to determine its effectiveness. It concludes that while source protection in New Zealand and the Commonwealth of Australia is relatively stable and comprehensive when compared to other jurisdictions, some refinement in approach is necessary in order to guarantee equitable protection for all journalists and their sources.

\section{Key Words}

$\underline{\text { Source Protection Disclosure Privilege Journalist }}$ 
I Introduction

II The Right to Keep Sources Confidential: A Snapshot of Source Protection in Jurisdictions of Influence
A The Value of Source Protection
B Is the 'Chilling Effect' Overstated?
C A Comparative Analysis of Source Protection Legislation
III Source Protection in New Zealand and Australia
A Introduction
B History of Source Protection in New Zealand
C Source Protection Today
D Influence of Section 68 on Australian Shield Laws
E Where Does That Leave Source Protection in New Zealand and the Commonwealth of Australia?

IV Are we in a good position internationally?
A Our Position Relative to Other Jurisdictions
B Is Reform Necessary?
C Foundational Issues
V Conclusion

VI Reference List 


\section{Introduction}

Democratic society relies on the free flow of information to the public, particularly information about the use and abuse of power. It is the role of the media to provide such information and in order to so accurately and without fear of censorship or punishment, they are dependent on a number of basic press freedoms (See discussion of Goodwin v United Kingdom on p. 9). One such press freedom, and the focus of this paper, is the right of a journalist to protect their confidential sources. This right is critical as many sources would not come forward with information if they could not be confident that journalists would protect their identity. ${ }^{1}$

Yet, despite the importance of source protection for a free press, the first explicit statutory recognition of this right anywhere in Australasia was not until 2006 when the New Zealand Parliament inserted s 68 into the nation's Evidence Act. $^{2}$ This section created a rebuttable presumption in favour of source confidentiality and vested sole discretion in determining when the public interest in disclosure will outweigh this presumption in the hands of judges of the High Court. ${ }^{3}$ It provided assurance to journalists that they would not be compelled to reveal their sources and also formed the backbone for journalistic protection laws in the Commonwealth of Australia, despite having being tested by the courts only once in the case of Police v Campbell. ${ }^{4}$

Some 8 years after the initial enactment of s 68, it is worth examining the success of this provision and the similarly worded provision in the Australian Commonwealth. This paper will explain why it is important that modern democratic nations provide journalists with strong guarantees of source protection and how other states have done so; examine whether s 68 and the shield laws in Australia provide sufficient protection for journalists; and discuss whether source protection on both sides of the Tasman Sea ought to be refined to provide clearer and more stringent protection for journalists.

\section{The Right to Keep Sources Confidential: A Snapshot of Source Protection in Jurisdictions of Influence}

\footnotetext{
${ }^{1}$ Ruth Costigan "Protection of Journalist's Sources" (2007) Public Law 464 at 464.

${ }^{2}$ Evidence Act 2006, s 68(1).

${ }^{3}$ Evidence Act, s 68(2).

${ }^{4}$ Police v Campbell [2010] 1 NZLR 483 (HC).
} 
Freedom of the press as a vehicle for comment on public issues is basic to a democratic system. $^{5}$ It is protected in the Universal Declaration of Human Rights and is considered fundamental to freedom of expression. ${ }^{6}$ It is awarded such high standing because the press bear responsibility for ensuring the public have a full and free flow of information. ${ }^{7}$ They are also charged with ensuring the public are well-informed about public issues and the people who represent them in places of power. ${ }^{8}$ The press, in this way, are the 'public watchdogs' of democratic society. ${ }^{9}$ Although they may be motivated by many considerations other than the high-minded task of informing the public, the public interest is served by their ability to uncover corruption, fraud and other anti-social behaviour. ${ }^{10}$ According to the Inter-American Court of Human Rights, "journalism is the primary manifestation of freedom of expression."11

Yet if they are to be effective in their role as a 'public watchdog', journalists need to be able to make sincere promises of confidentiality to sources that assist them in uncovering information. Much of the information which finds its way into the public domain is made available by individuals who would lack the resolve to give information if there were a risk that their identity may be disclosed. ${ }^{12}$ Confidentiality allows journalists to reassure such sources that they will remain anonymous, reducing fears of harm, embarrassment or legal entanglement. ${ }^{13}$ It gives journalists the ability to uncover corruption and misconduct in society that would otherwise be ignored or 'swept under the rug. ${ }^{\text {, }}$ As expressed by Lord Diplock, "if the identity of police informers were too readily liable to be disclosed in a court of law, the sources of information would dry up and the police would be hindered in their duty of preventing and detecting crime. Ordering journalists to disclose their sources can have similar consequences." 15

\footnotetext{
${ }^{5}$ Costigan, above $\mathrm{n} 1$, at 464 .

${ }^{6}$ United Nations Declaration of Human Rights (signed in 1948, entered into force 16 December 1949), art 19.

${ }^{7}$ Anthony L Fargo "The Year of Leaking Dangerously: Shadowy Sources, Jailed Journalists and the Uncertain Future of the Federal Journalist's Privilege" (2006) 14 Wm. \& Mary Bill Rts. J 1063 at 1073.

${ }^{8}$ Fargo, above n 7, at 1073.

${ }^{9}$ Observer and Guardian v the United Kingdom (13585/88) Court (Plenary), ECHR 26 November 1991.

${ }^{10}$ David Eady and ATH Smith Arlidge, Eady \& Smith on Contempt (4th ed, Sweet \& Maxwell, London, 2011) at $9-19$.

${ }^{11}$ Kelly Buchanan "Freedom of Expression and International Criminal Law: An Analysis of the Decision to Create a Testimonial Privilege for Journalists" (2004) 35 VUWLR 609.

${ }^{12}$ Michael Douglas “A Broad Reading of WA's Shield Laws” (2013) 18 MALR 377 at 381.

${ }^{13}$ Laurence B. Alexander "Looking Out for the Watchdogs: A Legislative Proposal Limiting the Newsgathering Privilege to Journalists in the Greatest Need of Protection for Sources and Information" 20 Yale Law \& Pol. Rev. 97 (2002) at 104.

${ }^{14}$ David Banisar Silencing Sources: An International Survey of Protections and Threats to Journalists' Sources (Privacy International, London, 2008) at 6.

${ }^{15}$ D v National Society for Prevention of Cruelty to Children [1978] AC 171, [1977] 2 WLR 201 (HL) at 218.
} 
Although source protection may encourage sources with improper motives (be they malicious, vexatious or dishonest) to come forward with information, it will also encourage sources with a clean conscience to disclose noteworthy information to journalists. ${ }^{16}$ While it seems intuitive to offer source protection only to individuals who come within the latter category, it is incredibly difficult to decipher the motive of a confidential source. ${ }^{17}$ Furthermore, regardless of a source's motive or conduct, any compelled disclosure may have a 'chilling effect' beyond the source in question. ${ }^{18}$ As stated by Sedley LJ in Interbrew, "the chilling effect of disclosure orders [is] an affirmative policy reason for ignoring motive in individual cases." 19

That compelled disclosure has a "chilling effect" on the free flow of information to the public is widely accepted. ${ }^{20}$ It negatively impacts the newspaper against which the order is directed and inhibits future sources' willingness to disclose information. ${ }^{21}$ If potential sources are put in the position of having to guess whether or not a court will order their name to be disclosed, they may not be prepared to take the risk that a court's decision will go against them. ${ }^{22}$ Comprehensive shield laws for journalists' sources help to 'thaw' this chilling effect, thereby preserving the free flow of information. ${ }^{23}$

B Is the 'Chilling Effect' Overstated?

Some commentators are however sceptical of the chilling effect disclosure has on future sources and on the media's ability to obtain honest information. ${ }^{24}$ They highlight that personal circumstances, practical realities and feelings of safety are what facilitate sources' willingness to reveal information to journalists, not the wording of the law. ${ }^{25}$ Long-term considerations, such as whether a judge might compel a reporter to identify them some years later, have little or no effect relative to short-term considerations such as whether their name appears in the paper the next day. ${ }^{26}$ In his affidavit submitted in Police $v$ Campbell, Steven Price played

\footnotetext{
${ }^{16}$ Costigan, above n 1 , at 474.

${ }^{17}$ See Interbrew SA v Financial Times Ltd [2002] EWCA Civ 274, [2002] EMLR 24 (HL) at [42]. "Motive is ordinarily pure guesswork in the absence of a source."

${ }^{18}$ Costigan, above $\mathrm{n} 1$, at 474.

${ }^{19}$ Interbrew, above $\mathrm{n} 17$, at [42].

${ }^{20}$ Eoin Carolan "The Implications of Media Fragmentation and Contemporary Democratic Discourse for

'Journalistic Privilege' and the Protection of Sources” (2013) 49 Irish Jurist 182 at 192.

${ }^{21}$ Financial Times Ltd v UK (2010) 50 EHRR 46 (Section IV, ECHR) at [59].

${ }^{22}$ Camelot Group Plc v Centaur Communications Ltd [1999] QB 124 at 138 C-E.

${ }^{23}$ Carolan, above n 20, at 192.

${ }^{24}$ See Randall D. Elliason “The Problems with the Reporter's Privilege” 57 Am. U. Law. Rev. 1341 (20072008); Steven Price "Evidence about the chilling effect of ordering journalists to burn confidential sources (19 June 2009) Media Law Journal <www.medialawjournal.co.nz>.

${ }^{25}$ Elliason, above n 24, at 1356.

${ }^{26}$ At 1356.
} 
down the importance of source protection, stating "the fact journalists can be ... compelled to reveal their source ... has not deterred such investigative journalism as has occurred."27

While his statement is correct in that much investigative journalism does occur despite weak source protection at law, it is impossible to assess how many more sources would have come forward but for fear of disclosure. Sources are influenced by a variety of factors in deciding to give up information and isolating the chilling effect of disclosure is inherently difficult. ${ }^{28}$ Though something must be said for the argument that sources do not care for the nature of the law, there is evidence to suggest that the stronger the perception of protection provided by the law the higher the quality of investigative reporting and the larger the quantity of investigative reports. ${ }^{29}$ This author is of the opinion that a perception of legal protection is at the very least of equal importance with journalistic honour as a consideration burdening would-be sources.

Long before any protection was given to sources at law journalists were writing stories based on confidential information. ${ }^{30}$ However, this was made possible only by a strict and unwavering adherence by journalists to their honour and ethical obligations. Sources were assured that journalists would place their ethical obligations of confidentiality above the law, even if it meant imprisonment for contempt. ${ }^{31}$ In such a landscape it was not so much a court's decision to require journalists to testify that had a chilling effect on sources but a journalist's willingness to comply with that decision. ${ }^{32}$

Today the landscape has changed. ${ }^{33}$ The notion that journalists must go to prison in order to keep a source confidential seems archaic and outdated. Furthermore a rule of practice which authorises contempt of court does not sit well with modern democratic processes. ${ }^{34}$ Although journalists today are still reluctant to give up their sources, they are far less likely to risk going to prison for their source. Instead it is now common for journalists to promise confidentiality only to the extent legally possible. ${ }^{35}$ In this landscape the chilling effect of a judge's decision is likely to be far more significant than a journalist's decision to comply. This paper contends that as the law has developed a nuanced approach to source protection through articulating the

\footnotetext{
${ }^{27}$ Steven Price "Evidence about the chilling effect of ordering journalists to burn confidential sources (19 June 2009) Media Law Journal <www.medialawjournal.co.nz>

${ }^{28}$ Price, above $\mathrm{n} 27$.

${ }^{29}$ Eileen M. Wirth "Impact of State Shield Laws on Investigative Reporting” 16 Newspaper Research J. 64 (1995).

${ }^{30}$ Fargo, above $\mathrm{n} 7$, at 1064 .

${ }^{31}$ Eady and Smith, above n 10, at 9-37; Attorney -General v Mulholland [1963] 2 QB 477 at 482.

${ }^{32}$ Eady and Smith, above n 10, at 9-37.

${ }^{33}$ Lori Robertson "Kind of Confidential" (2007) AJR June/July at 28.

${ }^{34}$ Eady and Smith, above n 10, at 9-37.

${ }^{35}$ Robertson, above n 33, at 28.
} 
circumstances in which confidences can and cannot be justifiably upheld, the level of protection offered by the law has begun to weigh more heavily on the minds of sources, perhaps outweighing journalistic honour. ${ }^{36}$

For potential sources who risk job loss, public ridicule and criminal sanctions upon revealing information, the extent of source protection offered at law is likely to be an important consideration. ${ }^{37}$ Stringent source protection should be encouraged in order to foster a perception that anonymous sources will be respected not just by journalists but also by the law.

\section{A Comparative Analysis of Source Protection Legislation}

Today over one hundred countries have legislation enshrining the principle of source anonymity. ${ }^{38}$ It is recognised in national constitutions, ${ }^{39}$ criminal codes, ${ }^{40}$ national or state laws, ${ }^{41}$ reinforced in the common law and incorporated in international obligations. ${ }^{42}$ The range of protection provided under these laws varies greatly, but at the bare minimum they all give print journalists the right to claim they are exempt from testifying as to the identity of a confidential source. ${ }^{43}$ The extent of the protection granted often depends on a nation or body's perception of the press and the weight given to freedom of expression. ${ }^{44}$ A brief overview of the levels of protection in jurisdictions with a strong influence on New Zealand and Australia's jurisprudence is included to help frame the discussion on source protection in Australasia.

\section{$1 \quad$ European Court of Human Rights}

The European Court of Human Rights (ECtHR) was established following the atrocities of the Second World War to ensure the enforcement and implementation of the European Convention of Human Rights. ${ }^{45}$ It places significant emphasis on protecting freedom of expression as a fundamental right and takes a liberal approach to source protection. ${ }^{46}$ As the linchpin for the protection of human rights in the 47 member States of the Council of Europe,

\footnotetext{
${ }^{36}$ Robertson, above n 33, at 28.

${ }^{37}$ Camelot Group Plc, above n 22, at 138 C-E.

${ }^{38}$ Banisar, above n 14, at 21.

${ }^{39}$ See the Freedom of the Press Act 1949 (Sweden), art. 3.

${ }^{40}$ See the Code of Criminal Procedure 2000 (Fr), s. 109.

${ }^{41}$ See Evidence Act 2006, s 68; Tenn. Code Ann. § 24-1-208 (Supp. 2000).

42 National Post v. Canada (2004) 236 DLR (4d) 551 (SCC); European Convention on Human Rights (signed 4

November 1950, entered into force on 3 September 1953) article 10.

${ }^{43}$ The Open Society Justice Initiative and others Amicus Curiae brief in Sanoma Uitgevers BV $v$ the Netherlands, December 2009 at 7.

${ }^{44}$ Banisar, above $\mathrm{n} \mathrm{14}$, at 12.

${ }^{45}$ The Conscience of Europe: 50 Years of the European Court of Human Rights $\left(2^{\text {nd }}\right.$ Ed, Third Millennium Information, London, 2010) at 16.

${ }^{46}$ At 17.
} 
and the model for other regional human rights courts around the globe, the ECtHR's jurisprudence on the protection of sources is of great influence. ${ }^{47}$

The ECtHR has heard a significant number of cases concerning journalists' sources and has repeatedly emphasised that Article 10 of the European Convention of Human Rights ${ }^{48}$ affords journalists the broadest scope of protection with regard to confidentiality. ${ }^{49}$ Arguably the most important of these cases is the case of Goodwin $v$ the United Kingdom. ${ }^{50}$ In that case, the court depicted the link between the role of the press and the protection of sources as follows: ${ }^{51}$

[39] Protection of sources is one of the basic conditions of press freedom... without such protection, sources may be deterred from assisting the press in informing the public on matters of public interest. As a result the vital public-watchdog role of the press may be undermined, and the ability of the press to provide accurate and reliable information may be adversely affected. An order of source disclosure cannot be compatible with Article 10 of the Convention unless it is justified by an overriding requirement in the public interest.

The Goodwin decision set the wheels in motion for source protection in Europe, establishing a minimum level of protection for all 47 signatories of the European Convention on Human Rights. ${ }^{52}$ It is clear from the decision in Goodwin that the ECtHR will order a journalist to disclose their source only when there is an 'over-riding public interest' in disclosure. This standard has been interpreted as requiring disclosure to be prescribed by law, ${ }^{53}$ to pursue a legitimate aim $^{54}$ and to be necessary in a free and just society. ${ }^{55}$ The final criterion has been further refined to require a pressing social need for disclosure which must be convincingly established. ${ }^{56}$ It is also worth noting that the ECtHR grants source protection to all members of the press not simply to journalists. According to the Council of Europe Guidelines, source protection applies to "any natural or legal person who is regularly and professionally engaged in the collection and dissemination of information to the public via any means of mass

\footnotetext{
47 At 24-26.

${ }^{48}$ European Convention on Human Rights (signed 4 November 1950, entered into force on 3 September 1953) article 10.

${ }^{49}$ See Goodwin v United Kingdom (1996) 22 EHRR 123 (Grand Chamber, ECHR); Nordisk Film \& TV A/S v Denmark (40485/02) First Section, ECHR 8 December 2005; Financial Times Ltd, above n 21; Sanoma Uitgevers BV v the Netherlands (38224/3) Grand Chamber, ECHR 14 September 2010; Nagla v Latvia (73469/10) Fourth Section, ECHR 16 July 2013.

${ }^{50}$ Goodwin v United Kingdom (1996) 22 EHRR 123 (Grand Chamber, ECHR).

${ }^{51}$ At [39].

${ }^{52}$ Eady and Smith, above n 10, at 9-2.

${ }^{53}$ Sanoma Uitgevers BV v the Netherlands (38224/3) Grand Chamber, ECHR 14 September 2010 at [81]-[83].

${ }^{54}$ Nordisk Film \& TV A/S v Denmark (40485/02) First Section, ECHR 8 December 2005 at 12.

${ }^{55}$ Financial Times Ltd v UK (2010) 50 EHRR 46 (Section IV, ECHR) at [71].

${ }^{56}$ Nagla v Latvia (73469/10) Fourth Section, ECHR 16 July 2013 at [96].
} 
communication." ${ }^{57}$ Goodwin has been affirmed in later ECtHR cases, and as a result of this decision most Council of Europe member states have since adopted source protection legislation in their domestic law. ${ }^{58}$

\section{$2 \quad$ United Kingdom}

Although Courts in the United Kingdom must take ECtHR decisions into account, they are not binding on domestic courts. ${ }^{59}$ The United Kingdom has thus been free to take a more pragmatic approach to source protection, perhaps reflecting a slightly less rights-based jurisprudence. ${ }^{60}$

Source protection in the United Kingdom is governed by the Contempt of Court Act 1981 (CCA) which states that source disclosure is warranted only when "necessary in the interests of justice or national security or for the prevention of disorder or crime". ${ }^{61}$ However the common law continues to have considerable influence on judicial decision-making. ${ }^{62}$ Before the CCA source disclosure was a question of public policy: a discretionary balancing exercise in which competing policy considerations of freedom of expression and justice were weighed equally. ${ }^{63}$ Although the CCA overruled this approach, requiring judges to decide whether disclosure was necessary as a question of fact rather than discretion, ${ }^{64}$ many judges were slow to adjust and continued to apply a discretionary balancing process thereafter. ${ }^{65}$

Prior to the Human Rights Act $1998,{ }^{66}$ the Goodwin line of cases exercised little, if any, influence on domestic courts in the United Kingdom. ${ }^{67}$ As soon as necessity was established as a question of fact a journalist's immunity disappeared, leaving press freedom in the realms of discretion. ${ }^{68}$ However that Act heralded a fundamental change in judicial reasoning. ${ }^{69}$ It aligned the standard of necessity with that of the ECtHR and firmly grounded it in the principle of freedom of expression. Protection of sources now remains the pre-imminent interest, even

\footnotetext{
${ }^{57}$ Council of Europe Recommendation No. R (2000) 7 on the right of journalists not to disclose their sources of information (Adopted by the Committee of Ministers on 8 March 2000, at the 701st meeting of the Ministers' Deputies).

${ }^{58}$ Banisar, above n 14, at 15.

${ }^{59}$ Ashworth Hospital Authority v MGN Ltd [2002] 1 WLR 2033 (HL) at [97].

${ }^{60}$ Eady and Smith, above n 10, at 9-7.

${ }^{61}$ Contempt of Court Act 1981 (UK), s 10.

${ }^{62}$ Eady and Smith, above n 10, at 9-13.

${ }^{63}$ See Attorney General v Clough [1963] 1 QB 773; British Steel Corp v Granada Television [1981] AC 1096 at 1196-1169.

${ }^{64}$ Eady and Smith, above n 10, at 9-87.

${ }^{65}$ Costigan, above $\mathrm{n} 1$, at 471.

${ }^{66}$ Human Rights Act 1998 (UK).

${ }^{67}$ Costigan, above $\mathrm{n} 1$, at 473 .

${ }^{68}$ At 469.

${ }^{69}$ At 472 .
} 
once the necessity of disclosure has been established. In Interbrew SA v Financial Times Ltd, Sedley LJ stated that: ${ }^{70}$

[32] ... the effect of sections 2 and 3 of the Human Rights Act 1998 is to require our judgment to conform so far as possible to the requirements of Article 10 [of the European Commission on Human Rights], and to take into account the [ECtHR]'s jurisprudence in determining what those requirements are. This must mean that, to be necessary within what is now the meaning of section 10, disclosure must meet a pressing social need, must be the only practical way of doing so, must be accompanied by safeguards against abuse and must not be such as to destroy the essence of the primary right.

Courts in the United Kingdom thus start with the assumption that the protection of sources is a matter of high public importance, that nothing less than necessity will suffice to over-ride it, and that necessity can only arise out of concern for another matter of high public importance. ${ }^{71}$ This is a strong step forward for source protection in the United Kingdom; however, the tendency of judges to engage in a balancing exercise means that protection for sources still remains lower than in the ECtHR. ${ }^{72}$ In every source protection case to come before the House of Lords (now the Supreme Court) since the Human Rights Act, the journalist has lost. ${ }^{73}$

\section{$3 \quad$ United States of America}

The only case concerning journalists' privilege heard by the United States Supreme Court, Branzburg $v$ Hayes, held that journalists do not have a constitutional right to refuse to testify before a grand jury about their sources of information. ${ }^{74}$ This was a surprising result considering the First Amendment's explicit protection of freedom of the press and it has been suggested that societal circumstances influenced the decision. ${ }^{75}$ The case was heard during a period of considerable civil unrest that saw police and prosecutors rely heavily on journalists for information about dissident groups. ${ }^{76}$

Whatever the reasoning behind the decision, the effect of Branzburg on journalistic source protection in the United States has been significant. There remains no legal or constitutional recognition for source protection at the national level and there have been many cases since of

\footnotetext{
${ }^{70}$ Interbrew, above n 17.

${ }^{71}$ Eady and Smith, above n 10, at 9-252.

${ }^{72}$ See Mersey Care NHS Trust v Ackroyd (No. 1) [2003] EWCA Civ 663, [2003] EMLR 36 at [69] per Tugendhat J.

${ }^{73}$ Costigan, above n 1 , at $486-7$.

${ }^{74}$ Branzburg $v$ Hayes, 408 US 665 (1972).

75 Vince Blasi “The Newsman's Privilege: An Empirical Study” (1971-1972) 70 Mich L. Rev. 229 at 239-240.

${ }^{76}$ At 239-240.
} 
journalists being sanctioned for refusing to disclose their sources. ${ }^{77}$ This is not to suggest that there is no source protection at all but it does suggest that it is unclear and easily overridden. In Branzburg, Justice Powell stated that for a subpoena to have merit, the party seeking disclosure must "convincingly show a substantial relation between the information sought and a subject of overriding and compelling state interest" ${ }^{78}$ yet this has not been interpreted strictly. While in theory this test may be analogised with the 'necessity standard' in the CCA (UK), in practice Branzburg permits disclosure simply where information is relevant and a journalist is a convenient source. ${ }^{79}$ According to a prominent First Amendment lawyer, Floyd Abrams, Branzburg "left the terrain in a manner where much more legal work needed to be done." 80

Fortunately, there has since been some recognition of stronger source protection in state courts. They have justified journalistic privilege on the basis of individual state constitutions, the common law and the federal rules of evidence. ${ }^{81}$ Some states have even established tests similar to the dissenting judgment of Justice Stewart in Branzburg. ${ }^{82}$ There appears to be a changing tide in American jurisprudence towards greater recognition of source protection. Perhaps if a case were to come before the Supreme Court today, the court would be more receptive of the argument that the First Amendment provides a qualified privilege for journalists, enabling them to withhold their confidential sources. ${ }^{83}$

\section{Discussion}

The legal systems examined above demonstrate that although journalistic source protection is not a deeply rooted principle at law, it is gaining momentum and is now afforded considerable weight in many jurisdictions. ${ }^{84}$ While the approaches discussed differ from those taken in New Zealand and Australia (see comparison on p. 24-25), an understanding of these differences promotes a more critical analysis of the Australasian position.

\footnotetext{
77 See Banisar, above n 14, at 90. Freelance writer Vanessa Leggett spent 168 days in jail for refusing to provide notes and tapes to the FBI; Judith Miller of the New York Times spent 85 days in jail for refusing to identify a presidential aide; and, Blogger Josh Wolf spent 226 days in Jail for refusing to provide an unpublished video.

${ }^{78}$ Branzburg, above $\mathrm{n} 74$, at 700-701.

${ }^{79}$ See re Special Proceedings 291 F Supp 2d 44 (DRI 2003) at 47-48. Reporter Jim Taricani was convicted of contempt charges in 2004 after refusing to reveal the source of a videotape showing a local official taking a bribe. The prosecutor later admitted that he was able to identify the source without the testimony of Taricani.

${ }^{80}$ Monica Dias “Branzburg Revisted?” (2002) 26(1) News Media and the Law 4 at 4.

${ }^{81}$ Buchanan, above n 11, at 635.

82 At 636; United States $v$ Burke 700 F 2d 70 ( $1^{\text {st }}$ Cir 1983).

${ }^{83}$ Kathleen Ann Ruane Journalists' Privilege: Overview of the Law and Legislation in Recent Congresses $\left(1^{\text {st }}\right.$ Ed, Congressional Research Service, Washington D.C, 2011) at 1.

${ }^{84}$ Banisar, above n 14, at 24.
} 


\section{Source Protection in Australia and New Zealand}

A Introduction

The following will address how source protection was historically approached in New Zealand and Australia prior to the enactment of legislative protections in the 2000s and consequently, how those legislative protections altered the legal and practical realities of source protection in both countries.

\section{B History of Source Protection in New Zealand}

New Zealand has long enjoyed a healthy commitment to press freedoms, including source protection. Ever since the inception of New Zealand's press in 1840 there is record of anonymous authors being protected and of journalists withholding their confidential sources. ${ }^{85}$ In 1894 a Royal Commission was established to ferret out the source of leaked information which appeared in the Evening Post. The editor, E.T. Gillon, refused to appear when subpoenaed and publicly called the Royal Commission an "impudent travesty of justice." 86 The editor regarded the duty to maintain confidential sources as "absolutely sacred." 87

\section{$1 \quad$ The newspaper rule}

In 1907 the newspaper rule, which protects newspapers from disclosing sources at pre-trial proceedings to defamation cases, was applied in New Zealand for the first time. ${ }^{88}$ In Hall v New Zealand Times Company Cooper $\mathrm{J}$ held that interrogatories asking from whom information was obtained will not be allowed in actions against newspapers, even where privilege or fair comment is pleaded and malice is directly at issue. ${ }^{89}$ Later Supreme Court cases such as McNabv Wellington Publishing Company, ${ }^{90}$ Isbey v New Zealand Broadcasting Corporation (No. 2) ${ }^{91}$ and Brill v Television Service One ${ }^{92}$ upheld the newspaper rule in relation to print journalism, radio and television. The overarching justification for the newspaper rule is consistent with the rationale behind source protection: the public interest in

\footnotetext{
${ }^{85}$ Devin M Smith "The Shields Pierce Easily: A Case for Fortifying the Journalists' Privilege in New Zealand" (2009) 18(1) Pacific Rim Law \& Policy Journal 217 at 224.

86 At 225.

${ }^{87}$ At 224.

${ }^{88}$ Hall v New Zealand Times Company (1907) 26 NZLR 1324 at 1326 (SC).

${ }^{89}$ At 1332.

${ }^{90}$ McNab v Wellington Publishing Company (1914) 33 NZLR 1362 (SC).

${ }^{91}$ Isbey $v$ New Zealand Broadcasting Corporation (No. 2) [1975] 2 NZLR 237 (SC).

92 Brill v Television Service One [1976] 1 NZLR 683 (SC).
} 
the dissemination of information. ${ }^{93}$ However it is limited in application, not extending beyond the interlocutory stages of discovery and interrogatories. ${ }^{94}$

\section{Evidence Amendment Act 1980 (No. 2), s 35}

Stronger source protection arose in 1980 by way of s 35 of the Evidence Amendment Act 1980 (No. 2). ${ }^{95}$ Section 35 gave courts the authority to excuse a witness from answering questions or producing documents if to do so would constitute a breach of a confidence. ${ }^{96}$ This removed any doubt surrounding judicial ability to exercise discretion in allowing a witness to decline to answer questions, as had previously existed under the common law. ${ }^{97}$ Confidences were protected under s 35 if they arose from any special relationship existing between a witness and a source of information, including the relationship between a journalist and his source. ${ }^{98}$ Section 35 required the courts to balance the significance of the evidence to the resolution of the issues in the proceedings against the likely effect of disclosure on the confidant or any other person, taking into consideration the nature of the confidence. ${ }^{99}$ When discussing Section 35 in $R v$ Cara, Potter J stated: ${ }^{100}$

[35] The court must weigh the competing public interest in freedom of expression, pursuant to which the Courts have long recognised that sources of information accessed by the media may require protection otherwise the flow of information in which freedom of speech relies may well be curtailed or may cease; and the interest of an accused person and of society generally in ensuring a fair trial for those charged under law.

The New Zealand courts approached s 35 cases in a similar manner to the common law approach of UK cases such as Attorney-General v Mulholland. ${ }^{101}$ Judges would exercise their discretion as to the competing public interests bearing on a particular case and decide accordingly.

\section{$3 \quad$ Law Commission criticisms}

In 1994 the Law Commission criticised s 35 on a number of grounds. Namely, the section placed a heavy burden on the party seeking to withhold information to satisfy the court of the

\footnotetext{
${ }^{93}$ Campbell, above n 4, at [51].

${ }^{94}$ At [51].

${ }^{95}$ Evidence Amendment Act 1980 (No. 2), s 35.

${ }^{96}$ Section 35.

${ }^{97}$ Law Commission Evidence Law: Privilege (NZLC PP23, 1994) at 109.

${ }^{98} R v$ Cara HC Auckland CRI-2004-004-6560, 2 June 2004.

${ }^{99}$ Campbell, above n 4, at [53].

${ }^{100} R$ v Cara, above n 98.

101 Attorney-General v Mulholland [1963] 2 QB 477.
} 
necessity to do so, it was ambiguous on the issue of whether a source's identity could be protected independent of a document withheld under the section, and it omitted to recognise the free flow of information as a matter of public interest. ${ }^{102}$ The Commission further noted the enactment of the New Zealand Bill of Rights Act 1990 gave scope to base journalistic privilege on the right to freedom of expression guaranteed by s $14 .^{103}$

In 1999 the Law Commission proposed introducing an express qualified privilege for journalists' confidences to the Evidence Act, which would shift the onus for disclosure onto the person seeking to have the source revealed. ${ }^{104}$ In 2006, s 68 of the Evidence Act was enacted in substantially similar terms to their recommendations. ${ }^{105}$ It offered journalists a qualified presumption in favour of source protection and overruled the common law.

\section{Source Protection Today}

\section{$1 \quad$ Section 68 of the Evidence Act}

One of the stated purposes of the Evidence Act was to protect rights of confidentiality and other important public interests, including the public interest in a free press. ${ }^{106}$ Section 68 provides for that purpose by creating a statutory presumption of non-disclosure of journalists' sources.

The default position is laid out in s $68(1):{ }^{107}$

If a journalist has promised an informant not to disclose the informant's identity, neither the journalist nor his employer is compellable in a civil or criminal proceeding to answer any question or produce any document that would disclose the identity of the informant or enable that identity to be discovered.

In order to invoke the presumption against disclosure, an individual must demonstrate to the court that they are a journalist and that a promise not to disclose a source's identity has been made. Once this is established all relevant documents and sources of information are prima facie protected. The court cannot depart from this position unless the public interest so demands. ${ }^{108}$

\footnotetext{
${ }^{102}$ Law Commission, above n 97, at 115.

103 At 111.

104 At 81.

${ }^{105}$ Evidence Act 2006, s 68.

106 Section 6.

107 Section 68(1).

${ }^{108}$ Campbell, above n 4, at [93]; Evidence Act 2006, s 68.
} 
The wording of the statute is explicit in its application solely to the media. ${ }^{109}$ Unlike s 10 of the CCA (UK) which can be invoked by anyone, ${ }^{110} \mathrm{~s} 68(1)$ is "limited and specific", applying only to journalists and their employers. ${ }^{111} \mathrm{~A}$ journalist is defined in the statute as "a person who in the normal course of that person's work may be given information by an informant in the expectation that the information may be published in a news medium."112 News medium is defined as "a medium for the dissemination to the public or a section of the public of news and observations on news." 113 These definitions appear to narrow the scope of the section, suggesting s68 (1) only protects traditional forms of journalism, such as print and television, and does not extend to modern news mediums such as blogs. However this is a contentious and undecided issue currently before the High Court in Blomfeld v Slater, on appeal from the District Court decision of Slater v Blomfeld. ${ }^{114}$

In the District Court Judge Blackie adopted a narrow approach. ${ }^{115}$ His Honour held that a blog website was not a means for the dissemination of news or observation on news and so did not deserve the protection afforded by s $68 .{ }^{116}$ Although no judgment has been given on appeal, the Amicus Curiae submission to the case provides insight into the scope of the statute. ${ }^{117}$ In that submission, Julian Miles QC discusses the definitions of journalist and news medium. He finds that 'normal course of work' requires a degree of regularity and consistency in activities said to constitute work; that full-time employment should not be a pre-requisite to journalism; and that a subjective belief that one is not a journalist is inconclusive. ${ }^{118}$ While he leaves the issue of whether 'work' should be construed narrowly or broadly to the court, he attests that there is little merit in constraining the definition to paid employees of the traditional media. ${ }^{119}$ If s 68 is applied to bloggers and modern information mediums in Slater v Blomfeld, it will have a profound effect on the scope of source protection in New Zealand. ${ }^{120}$

\footnotetext{
${ }^{109}$ Evidence Act, s 68.

${ }^{110}$ Contempt of Court Act 1981 (UK), s 10.

111 Campbell, above n 4, at [84].

112 Evidence Act, s 68(5).

113 Section 68(5).

114 See Blomfeld v Slater CIV-2012-092-001969, 2 September 2013; Julian Miles Amicus Curiae Submission in Slater v Blomfeld CIV-2013-404-5218, 20 June 2014.

115 Blomfeld v Slater CIV-2012-092-001969, 2 September 2013 at [15].

116 At [15].

117 Julian Miles Amicus Curiae Submission in Slater v Blomfeld CIV-2013-404-5218, 20 June 2014.

118 At [35], [52].

119 At [69].

120 At [14].
} 
If s 68(1) is successfully invoked, an individual can refuse to answer relevant testimonial questions and can refuse to produce documents that explicitly disclose their source or would enable their source's identity to be discovered. ${ }^{121}$ A wide scope avoids parties seeking disclosure from using the reporter's notes as a 'back-door method' of acquiring the informant's identity. ${ }^{122}$

In circumstances when a journalist refuses to give up his source in accordance with s 68(1), it is then for the court to consider whether the presumption of non-disclosure stands or whether it is outweighed by the public interest in disclosure (see s 68(2)). The right of a journalist to protect their sources should not be departed from lightly. ${ }^{123}$ In Campbell, Randerson J stated "departure will only be permitted after a careful weighing of each of the statutory considerations." "124

\section{$4 \quad$ When is the presumption of non-disclosure overridden?}

Section 68(2) lays out the circumstances in which s 68(1) may be overridden. It is worded as follows: ${ }^{125}$
A judge of the High Court may order that subsection (1) is not to apply if satisfied by a party to a civil or criminal proceeding that, having regard to the issues to be determined in that proceeding, the public interest in the disclosure of evidence of the informant outweighs:
a) Any likely adverse effect of disclosure on the informant or any other person; and;
b) The public interest in the communication of facts and opinion to the public by the news media and, accordingly also, in the ability of the news media to access sources of facts.

This subsection requires a Judge of the High Court to weigh competing public interests in deciding whether to over-ride the presumption of non-disclosure. There is no evidential onus on the defendant requiring them to establish that the need for disclosure outweighs that of confidentiality; a judge must simply be satisfied, or 'make up his mind', that disclosure is warranted. ${ }^{126}$ This is not a particularly heavy burden on the party seeking disclosure ${ }^{127}$ and while it is commendable that journalists no longer have to convince the court of the need for

\footnotetext{
${ }^{121}$ Smith, above n 85, at 227.

122 At 227.

${ }^{123}$ Campbell, above n 4, at [93].

124 At [93].

${ }^{125}$ Evidence Act 2006, s 68(2).

${ }^{126}$ Campbell, above $\mathrm{n}$ 4, at [87].

${ }^{127}$ Miles, above n 117, at [87].
} 
confidentiality, the broad ambit of this judicial balancing may allow s68(1) to be displaced in potentially unwarranted circumstances. ${ }^{128}$

Judges are not required to show that disclosure is necessary as is required under the UK provision, ${ }^{129}$ or that the circumstances are unusual or exceptional as was argued by the defendants in Campbell. ${ }^{130}$ They must simply show that on balance the public interest in disclosure outweighs that of free expression. There is a risk that under the current provisions the Courts might prioritise the public interest in evidentiary disclosure at the expense of source confidentiality. This occurred in a number of cases before the enactment of this section. ${ }^{131}$

\section{$5 \quad$ What factors make up the balancing test?}

The kinds of factors which must be considered when balancing public interests are not set out in the statute; however drawing on authorities from other jurisdictions, Randerson $\mathrm{J}$ in Campbell attempted to provide some clarification. ${ }^{132}$

His Honour stated that in considering the weight to be attached to the public interest in the disclosure of evidence, it will be relevant to consider any other means available to obtain the information sought. If the identity of the informant can be obtained by an alternative route, journalistic protection should not normally be overridden. ${ }^{133}$ Furthermore the significance of the information to the prosecution's case is a relevant consideration. The more crucial the identity of the informant, the greater the weight to be attached to the public interest in disclosure of their identity. ${ }^{134}$ It must be more than merely "desirable or nice to have." ${ }^{135}$ In a criminal case, Randerson $\mathrm{J}$ viewed the importance of the charge as another relevant consideration. Prosecution for a minor offence is unlikely to carry a sufficient degree of public interest. $^{136}$

In terms of considerations weighing against disclosure, Randerson $\mathrm{J}$ stated that when considering any likely adverse effect on the informant or any other person, a determination should be made regarding whether the informant or any other person is likely to suffer some form of harm if their identity is disclosed. ${ }^{137}$ According to Julian Miles QC, this encompasses

\footnotetext{
${ }^{128}$ Smith, above n 85, at 228.

${ }^{129}$ Contempt of Court Act 1981 (UK), s 10.

${ }^{130}$ Campbell, above $\mathrm{n} 4$, at [91].

${ }^{131} R v$ Patel CRI-2004-004-014009, 27 October 2005.

132 Campbell, above n 4, at [92]-[103].

${ }^{133}$ Campbell, above n 4, at [96].

134 At [97].

135 At [97].

${ }^{136}$ At [98].

137 At [100].
} 
a risk of physical harm or damage to property, as well as any loss of employment, status, reputation or any other adverse familial consequences. ${ }^{138}$ Regarding the public interest in the ability of the media to access sources of facts, Randerson $\mathrm{J}$ acknowledged that judges must consider the effect of disclosure on the reputation and integrity of the journalist concerned and any 'chilling effect' disclosure may have on members of the public who might communicate confidential material to the media in future. ${ }^{139}$

\section{What happens when there is a strong public interest in disclosure?}

Many cases concerning source disclosure are by no means black and white; for that reason, an order for disclosure does not directly follow from a finding that the public interest in disclosure outweighs the interests of confidentiality. By virtue of section 68(3), a judge may order full disclosure, he is no obliged to. ${ }^{140}$ Subsection 3 states: "the Judge may make the order subject to any terms and conditions that the Judge thinks appropriate." 141

This subsection gives judges considerable discretion in borderline cases and means that a finding against the journalist may not necessarily entail disclosure of their source. Campbell was one such borderline case; Randerson J was willing to override the presumption in s 68(1) but did not order disclosure. ${ }^{142}$ In that case, the Police sought to uncover the identity of an anonymous man who admitted to stealing 9 Victoria Cross war medals and who had agreed to an interview on the plaintiff journalist's show following the return of said medals. ${ }^{143}$ His Honour held that s 68(1) was overridden on the facts, yet having reached that conclusion he did not order Campbell (a journalist for TV3) to disclose his source. ${ }^{144}$ Instead his Honour asked for further details and related evidence from TV3 which was not protected by s $68(1) .{ }^{145}$ He did not see it as necessary to order disclosure given that there were a number of other pieces of evidence which would likely prove sufficient to identify the thief for the purposes of prosecution. ${ }^{146}$ In so doing, his Honour implied that even where the public interest in free expression is outweighed, disclosure should be a method of last resort.

\footnotetext{
${ }^{138}$ Miles, above $\mathrm{n}$ 117, at [93].

${ }^{139}$ Campbell, above $\mathrm{n} 4$, at [101].

${ }^{140}$ Evidence Act 2006, s68(3).

${ }^{141}$ Section 68(3).

142 Campbell, above n 4, at [115].

143 At [1-7].

144 At [104-114].

145 At [116].

146 At [117-118].
} 
1

History of source protection in the Australian Commonwealth

Source protection in Australia has followed a broadly similar path to New Zealand. The legislation in force today contains a presumption of non-disclosure, modelled largely off New Zealand's s $68 .{ }^{147}$ However unlike New Zealand, a non-descript common law approach remained pre-eminent right up until 2007. ${ }^{148}$ While the newspaper rule offered some protection during the interlocutory stage of a defamation action, in other circumstances journalists were forced to reveal their sources whenever disclosure was in the interests of justice. ${ }^{149}$ A number of early cases explicitly confirmed that undertakings given to sources by journalists could not "stand in the way of the imperative necessity of revealing truth in the witness box." 150

New South Wales (NSW) was the first state to provide some level of protection for journalists' sources. In 1997 it incorporated broad statutory protections for professional confidential relationships in an amendment of the Evidence Act 1995 (NSW). ${ }^{151}$ Unfortunately no other Australian jurisdiction followed suit for another decade. ${ }^{152}$ Furthermore, this provision was not specific to journalists and a presumption in favour of disclosure rendered its protections practically useless. ${ }^{153}$

\section{A Turning Point? $R v$ Gerard Thomas McManus and Michael Harvey}

Over the last 20 years, nine Australian journalists have been convicted for not revealing their sources; ${ }^{154}$ however, it was not until the highly publicised conviction of Gerard McManus and Michael Harvey for contempt of court in 2007 that the weakness of source protection in Australia began to gain public attention. ${ }^{155}$ These 2 journalists were each fined $\$ 7000$ after refusing to identify the source of a confidential communication and their trial prompted widespread debate on the issue of source protection in Australia. ${ }^{156}$ The Commonwealth responded with the Evidence Amendment (Journalists' Privilege) Act 2007 (Cth), yet this Act

\footnotetext{
${ }^{147}$ Evidence Act 1995 (Cth), s126H.

${ }^{148}$ See McGuinness v Attorney-General (Vic) (1940) 63 CLR 73 at 85-6 per Latham CJ, at 102-4 per Dixon J. See also the approach taken by the High Court in John Fairfax \& Sons Ltd v Cojuangco (1988) 165 CLR 346.

149 John Fairfax \& Sons Ltd v Cojuangco (1988) 165 CLR 346 at 354.

${ }^{150}$ McGuinnes v Attorney-General (Vic) (1940) 63 CLR 73 at 102.

${ }^{151}$ Evidence Act 1995 (NSW), s126.

152 Nicolee Dixon Shield Laws for Journalists (Queensland Parliamentary Library and Research Service, Research Brief No. 3, February 2012) at 5.

${ }^{153}$ NRMA v John Fairfax Publications [2002] NSWSC 563 at [169]-[170].

154 (25 October 2010) 3 AUSPD Cth HR 1242.

${ }^{155} R$ v Gerard Thomas McManus \& Michael Harvey [2007] VCC 619.

${ }^{156}$ Kirsty Magarey Evidence Amendment (Journalists Privilege) Bill 2010 (No. 2) Parliament of Australia, Bills Digest No 39 2010-11, November 2010 at 3.
} 
was modelled largely on the NSW provisions and gave rise to the same misgivings. ${ }^{157}$ It differed only in limiting the protection to journalists and in favouring national security over other interests to be balanced. ${ }^{158}$ Nonetheless it can be commended for introducing some level of source protection, and for setting the wheels in motion for a number of member's bills which sought to strengthen Australia's shield laws. ${ }^{159}$

\section{$3 \quad$ Further amendments to the Evidence Act 1995}

In 2009 the Evidence Amendment (Journalists' Privilege) Bill attempted to expand the matters which a court could consider when exercising its discretion on whether or not to protect a confidential source. ${ }^{160}$ Yet the Bill lapsed before being enacted. In committee the most common objection to the Bill was its retention of a presumption in favour of disclosure. ${ }^{161}$

Less than a year later, 2 private member's bills were introduced within weeks of each other to the House of Representatives (the Wickie Bill) ${ }^{162}$ and the Senate (the Brandis Bill), ${ }^{163}$ both addressing this very objection. ${ }^{164}$ The respective bills sought to provide for a rebuttable presumption that journalists' sources be privileged; the Brandis Bill further extended the privilege to other professional confidential relationships. ${ }^{165}$ The former went on to pass the House of Representatives with bipartisan support and was enacted by the Senate on 3 March 2011. ${ }^{166}$ The latter did not eventuate.

\section{$4 \quad$ Similarities between the Commonwealth provisions and Section 68}

The operative provision of the Evidence Amendment (Journalists' Privilege) Act 2011, s $126 \mathrm{H}$, was based closely on New Zealand's s $68 .{ }^{167}$ It contains an almost identically worded qualified presumption in favour of non-disclosure. Given the similarity, it is now appropriate to talk of the Australasian approach to source protection. ${ }^{168}$ Any points of difference in the wording or application of the Act are examined below.

\footnotetext{
${ }^{157}$ Dixon, above n 152 , at 5.

158 Matthew Tracey "Journalist Shield Laws in Australia” (2010) 29(2) Communications Law Bulletin 12 at 13.

${ }^{159}$ Magarey, above n 156, at 3.

${ }^{160}$ See Evidence Amendment (Journalists’ Privilege) Bill 2009 (Cth).

${ }^{161}$ Magarey, above n 156, at 4.

162 Evidence Amendment (Journalists' Privilege) Bill 2010 (Cth).

${ }^{163}$ Evidence Amendment (Journalists’ Privilege) Bill 2010 (Cth) (No. 2).

${ }^{164}$ Dixon, above $\mathrm{n} 152$, at 6.

165 See Magarey, above n 156, at 9.

166 Evidence Amendment (Journalists' Privilege) Act 2011 (Cth).

${ }^{167}$ See Evidence Act 2006, s68; Evidence Act 1995 (Cth), s126H.

${ }^{168}$ Western Australia (WA), Victoria (Vic) and New South Wales (NSW) all have source protection legislation expressed in similar terms to the Evidence Amendment (Journalists' Privilege) Act 2011 (Cth), s 126H. See the Evidence Act 1906 (WA), s 20I; Evidence Act 2008 (Vic), s 126K(1); Evidence Act 1995 (NSW), s 126K(1); Evidence Act 2011 (ACT), s 126K(1).
} 
a) Who is covered by the provisions?

In the original drafting of s $126 \mathrm{G}$ (the definitions section), the definitions of a journalist and of a news medium were the same as in New Zealand. ${ }^{169}$ However, amendments moved on behalf of the Australian Greens broadened both the definition of journalist and news medium to be more inclusive of bloggers, citizen journalists and documentary filmmakers. ${ }^{170}$ The definitions as enacted differ from New Zealand in defining a journalist as someone who is "engaged and active in the publication of news" and in defining a news medium as "any medium for the dissemination... of news and observations of news". ${ }^{171}$ These changes expand the scope of protection to include anyone engaged in the process of journalism, "no matter who they are or in what medium they publish." 172 While the New Zealand High Court may overturn Judge Blackie's decision to deny bloggers protection under s68(5), as the law currently stands in New Zealand only traditional, paid journalists can be sure of protection. ${ }^{173}$ It is also worth highlighting that the definition of informant in $\mathrm{s} 126 \mathrm{G}$ remains identical to New Zealand in its focus on a person who gives information to a journalist "in the normal course of the journalist's work" 174 and so is inconsistent with the broader definition of a journalist in the Commonwealth statute. This inconsistency should be rectified to avoid confusion.

b) Who can override the presumption of non-disclosure?

In New Zealand only a judge of the High Court has the authority to override the presumption of non-disclosure, meaning the presumption in favour of non-disclosure is absolute in lower courts and tribunals. ${ }^{175}$ This restriction serves to limit the discretionary element of the privilege and ensure consistency. In contrast, the Commonwealth presumption can be overridden in all applicable courts. ${ }^{176}$ As the Act applies in the federal courts, ACT courts and in any other Australia court for an offence against the Commonwealth, there is the potential for source protections to be overridden in the lower courts and for an inconsistent approach to be applied between cases.

\footnotetext{
169 See Evidence Act 2006, s 68(5).

170 (25 October 2010) 3 AUSPD Cth HR 1241; Dixon, above n 152, at 7.

${ }^{171}$ Evidence Act 1995 (Cth), s126H; Magarey, above n 156, at 4.

172 (25 October 2010) 3 AUSPD Cth HR 1241.

173 Blomfeld v Slater, above n 115, at [15].

${ }^{174}$ Evidence Act 1995 (Cth), s 126G.

175 Evidence Act 2006, s 68(2).

${ }^{176}$ Evidence Act 1995 (Cth), s 126H(2).
} 
c) How has the Commonwealth source protection been applied in the courts?

Section $126 \mathrm{H}$ has only been invoked in one case to date, the case of Ashby v Commonwealth of Australia (No. 2). ${ }^{177}$ Interestingly, despite the similarities in the legislative provisions, that case did not refer to the leading New Zealand case of Campbell. ${ }^{178}$

In Ashby Rares $\mathbf{J}$ was required to consider whether a journalist could claim the protection offered by the Commonwealth legislation where the most likely source of the information was already publicly known as one of his informants. ${ }^{179}$ In applying the statute to the facts, his Honour was of the opinion that if the informant had already identified himself or herself as the journalist's source, it would be inconsistent with $\mathrm{s} 126 \mathrm{H}$ to allow the journalist to refuse to answer questions or produce documents that would confirm what had already been disclosed. ${ }^{180}$ On that basis he stood the subpoena over for one week in order that the plaintiff might readdress the question of whether he was entitled to assert the privilege.

Whether source protection can be claimed when an informant's identity is already public knowledge is an open issue and Rares $\mathbf{J}$ was open to deny source protection on that basis; ${ }^{181}$ however, it is concerning that he did not first apply the statutory presumption and then assess whether it should be overridden. ${ }^{182}$ The statutory presumption covered the plaintiff as an investigative print journalist who had obtained information on the basis of a promise of confidentiality. ${ }^{183}$ His Honour should have acknowledged this and thereafter engaged in an assessment of whether the public interest in determining the information outweighed the effect on the source, any other individual or the public interest in free expression. ${ }^{184}$

This would have been consistent with the wording of s126H and with the approach taken in Campbell. ${ }^{185}$ Although it may not have altered the result, it would have set a much clearer standard for judges applying the statute in later cases. The approach taken by his Honour did not lay out a straightforward test or indicate the kinds of factors to be considered when weighing the public interests, suggesting that Rares $\mathrm{J}$ was not certain of the process to be followed and perhaps indicating that $\mathrm{s} 126 \mathrm{H}$ will be interpreted narrowly by Commonwealth

\footnotetext{
${ }^{177}$ Ashby v Commonwealth of Australia (No. 2) [2012] FCA 766.

${ }^{178}$ Campbell, above n 4.

${ }^{179}$ Ashby, above n 177, at [9] and [12].

180 At [30].

181 At [34].

182 Evidence Act 1995 (Cth), s 126H.

${ }^{183}$ Ashby, above n 177, at [8].

${ }^{184}$ Evidence Act 1995 (Cth), s 126H.

${ }^{185}$ Campbell, above $\mathrm{n} 4$.
} 
judges. ${ }^{186}$ Of particular concern, his Honour made no outright distinction between sources which are already public known and sources which can be identified by other means. This casts doubt on whether independent avenues of inquiry must first be carried out before disclosure will be ordered. ${ }^{187}$ This principle is well-established in the $\mathrm{UK}^{188}$ and has been affirmed in New Zealand in $R v$ Cara and Police $v$ Campbell. ${ }^{189}$ It should not be departed from lightly.

E Where Does That Leave Source Protection in New Zealand and the Commonwealth of Australia?

The cases of Campbell and Ashby demonstrate that source protection legislation is difficult to apply in practice. ${ }^{190}$ In Ashby, his Honour struggled to apply the balancing test and while the approach of Randerson $\mathbf{J}$ in Campbell is to be commended, it demonstrates the inherently discretionary nature of the Australasian approach. These cases also demonstrate a somewhat disparate judicial approach to source protection in New Zealand and the Commonwealth of Australia despite very similar statutes. Some uncertainty continues to surround who can claim protection, who can override it and when the presumption will be overridden. As source protection measures have a chilling effect when they are perceived to be uncertain or narrow, we must attempt to remedy these misgivings. ${ }^{191}$

\section{IV $\quad$ Are we in a good position internationally?}

\section{A Our Position Relative to Other Jurisdictions}

Source protection in Australasia has evolved considerably over the last 30 years, moving from a landscape of virtually no protection to a now strong presumption against disclosure. ${ }^{192}$ This is commendable and traditional journalists can now give strong assurance to sources that their identity is presumed at law to be confidential and will only be exposed in certain circumstances.

On the other hand, even traditional journalists cannot promise to sources that their identity will be disclosed only in 'exceptional or extraordinary circumstances', or even only where

\footnotetext{
${ }^{186}$ Ashby, above n 177, at [23].

${ }^{187}$ See Saunders v Punch Limited [1998] 1 WLR 986 at 997C-E.

${ }^{188}$ See Special Hospitals Service Authority v Hyde (1994) 20 BMLR 75; Saunders, above n 187, at 997C-E.

${ }^{189}$ See discussion in Campbell, above n 4, at [96]; $R$ v Cara HC Auckland CRI-2004-004-6560, 2 June 2004 at [22].

${ }^{190}$ Campbell, above n 4; Ashby, above n 177.

${ }^{191}$ Carolan, above n 20, at 192.

192 Compare Evidence Amendment Act 1980 (No. 2), s 35 and Evidence Act 2006, s 68(3); Compare also

McGuinness v Attorney-General (Vic) (1940) 63 CLR 73 at 102 and Evidence Act 1995 (Cth), s126H.
} 
'necessary.' ${ }^{193}$ If the public interest in justice is deemed to outweigh the interest in nondisclosure, there is nothing a journalist can do to protect their source without being held in contempt of court. ${ }^{194}$

On a spectrum of protection ranging from a presumption in favour of disclosure to absolute protection for confidential sources, New Zealand and Australia currently sit somewhere towards the upper end. The presumption in favour of non-disclosure, which can be only overridden when the public interest so demands, provides relatively strong assurance to informants that their identities will be protected. It is above the level provided at a federal level in the United States, where journalists must rely on a bare balancing of interests. ${ }^{195}$ Yet it is lower than the presumption in the United Kingdom which can only be overridden where "necessary in the interests of justice or national security or for the prevention of disorder or crime." 196

B Is reform necessary?

Given this relatively stable position comparative to other common law nations, dramatic reform is not urgently required; however it is essential that both New Zealand and Australia 'iron out the kinks' in our source protection legislation. At present there are a number of weaknesses which threaten to unravel the protections if not addressed judicially or by parliament.

\section{$1 \quad$ Definitions}

Some of the weaknesses inherent in our source protection legislation relate to how journalists, news media and informants are defined. In New Zealand they are defined too narrowly, risking exclusion for modern news mediums such as blogs. ${ }^{197}$ In the Commonwealth of Australia they are defined inconsistently, in that while bloggers are included, the definition of an informant still rests on the same narrow construction of language that is used in New Zealand. ${ }^{198}$ These definitions need to be clarified by the legislature so that they can be applied consistently and broadly in the courts.

\footnotetext{
193 Campbell, above n 4, at [89].

${ }^{194}$ Evidence Act 2006, s 68(2).

${ }^{195}$ Branzburg $v$ Hayes, above n 74, at 703-708; $R$ v National Post (2010) 1 SCR 477 (SCC) at [28] and [34]

196 See Contempt of Court Act 1981 (UK), s 10; Interbrew, above n 17, at 32.

${ }^{197}$ See Evidence Act 2006, s 68(5); Blomfeld v Slater, above n 115, at [15].

${ }^{198}$ Evidence Act 1995 (Cth), s 126G.
} 
Ashby serves as a warning that the Commonwealth courts may not yet appreciate the precise nature and exercise of the protection under $\mathrm{s} 126 \mathrm{H} .{ }^{199}$ When the CCA was enacted in the United Kingdom, it was some time before judges fully grasped the meaning of a "necessity standard.' 200 The common law balancing test dominated judicial reasoning well into the late 1990s, with the consequence that the statutory requirement of necessity was not implemented appropriately or to a sufficiently demanding standard. ${ }^{201}$

While the disclosure standard in Australasia is not one of necessity, the legislation is still a considerable break from the balancing approach in existence prior. Both s68 (NZ) and s126H (AUS) establish a presumption in favour of protection but give judges wide scope to determine whether disclosure is or is not in the public interest. There is a risk that the same resistance to change as occurred in the UK may hinder judges from giving full effect to this presumption. ${ }^{202}$

\section{$3 \quad$ Statutory Wording}

The Law Commission paper on which s 68 was based recommended that where possible a less-intrusive method for acquiring a source's identity should be adopted. In other words, "alternative avenues should be exhausted before ordering a journalist to disclose." 203 While this was a consideration in Campbell, ${ }^{204}$ it was never explicitly incorporated in legislation and risks being forgotten as it was in Ashby. ${ }^{205}$ It is the opinion of the author that this is a principle of sufficient importance to warrant inclusion in statute, preferably as one of the terms to be considered before making an order of disclosure. Alternatively, the language of the statutes could be altered to permit disclosure only when the source's identity is 'highly material and relevant' to the prosecution's case. ${ }^{206}$

\section{Foundational issues}

Source protection in Australasia relies on the presumption that judges are qualified to balance freedom of the press and trial rights in deciding whether or not to order disclosure. The use of the term "outweighs" in the respective statutes suggests that if a judge feels the scales tip even

\footnotetext{
${ }^{199}$ Ashby, above n 177, at [29] and [33].

${ }^{200}$ Costigan, above $\mathrm{n} 1$, at 467.

201 At 467.

202 At 471.

${ }^{203}$ Law Commission, above n 97, at 115.

${ }^{204}$ Campbell, above $\mathrm{n} 4$, at [96].

${ }^{205}$ Ashby, above n 177, at [30].

206 Smith, above n 85, at 246.
} 
slightly in favour of disclosure they are justified in compelling a journalist to reveal their source. ${ }^{207}$ Yet judges have more concrete experience with the court system than with the media. ${ }^{208}$ They readily understand the impact of withholding testimony or evidence, but have less comprehension of the impact on society of disclosure of confidential sources. ${ }^{209}$ Given this predisposition, any statute necessitating a balancing test is likely to unduly favour the party seeking disclosure.

On this basis, a less discretionary approach to source protection is warranted. While the United Kingdom method is not fool-proof, its high standard for disclosure, that being "necessary in the interests of justice or national security or for the prevention of disorder or crime" has merit. ${ }^{210}$ It is broadly consistent with the current approach; yet it directs judges away from a balancing test, and towards an exercise of objective judgment. ${ }^{211}$ It does not involve a tradeoff of competing interests but a question of fact as to whether the 'necessity' standard has been met. ${ }^{212}$ Importing such a requirement to Australasia would prevent judges from using their discretion to whittle down source protection.

\section{Conclusion}

The level of protection which ought to be given to journalists' sources at law is controversial. On the one hand, confidentiality enables journalists to present critical information to the public which may otherwise be unattainable; yet on the other, that same confidentiality prevents parties to legal proceedings from obtaining all the evidence relevant to their case. ${ }^{213} \mathrm{~A}$ judicial balancing of the two interests is the most obvious method for determining whether a journalist should give up their source, yet it presupposes that the scales are in equilibrium at the outset of the exercise. ${ }^{214}$ In reality, a growing international jurisprudence suggests otherwise. ${ }^{215}$

In recognition of the need to protect sources more stringently, over 100 nations have implemented some level of protection in statute. ${ }^{216}$ This paper canvassed some of the statutory provisions in jurisdictions with an impact on Australasia. It concluded that while the extent of

\footnotetext{
${ }^{207}$ Smith, above n 85, at 246.

${ }^{208}$ At 237.

209 At 237.

${ }^{210}$ Contempt of Court Act 1981 (UK), s 10

211 Costigan, above n 1 , at 469.

212 At 467.

${ }^{213}$ Sara Phung "Function Not Form: Protecting Sources of Bloggers" (2012) 17 MALR 121 at 128.

${ }^{214}$ Eady and Smith, above n 10, at 9-17

215 At 9-18.

${ }^{216}$ Banisar, above n 14, at 21.
} 
protection depends largely on a nation or body's perception of the press, there is a general trend towards statutory recognition of a journalist's right to protect their source.

Recent developments in New Zealand and Australia are consistent with this trend. Both countries have reformed their source protection legislation in the last decade, and both can be commended for making non-disclosure the default position and for providing stronger assurance to journalists that the law respects their ethical obligations. Yet, both still contain elements of the common law balancing test and have proved difficult to apply in practice. A number of issues have been identified and some refinements have been suggested in this paper in order that source protection legislation be easily understood by informants and accurately applied by the courts, both in New Zealand and Australia.

[Word Count Excluding Footnotes, Reference List and Cover Page - 8,044 words] 


\section{Reference List}

A Cases

$1 \quad$ New Zealand

Blomfeld v Slater CIV-2012-092-001969, 2 September 2013.

Brill v Television Service One [1976] 1 NZLR 683 (SC).

Hall v New Zealand Times Company (1907) 26 NZLR 1324 (SC).

Isbey v New Zealand Broadcasting Corporation (No. 2) [1975] 2 NZLR 237 (SC).

McNab v Wellington Publishing Company (1914) 33 NZLR 1362 (SC).

Police v Campbell [2010] 1 NZLR 483 (HC).

$R v$ Cara HC Auckland CRI-2004-004-6560, 2 June 2004.

$R v$ Patel CRI-2004-004-014009, 27 October 2005.

$2 \quad$ Australia

Ashby v Commonwealth of Australia (No. 2) [2012] FCA 766.

DPP v Luders Court of Petty Sessions of Western Australia, No 27602 of 1989.

John Fairfax \& Sons Ltd v Cojuangco (1988) 165 CLR 346.

McGuinness v Attorney-General (Vic) (1940) 63 CLR 73.

NRMA v John Fairfax Publications [2002] NSWSC 563.

$R v$ Budd Supreme Court of Queensland, No 36188 of 1992, Brisbane, 20 March 1992.

$R v$ Gerard Thomas McManus \& Michael Harvey [2007] VCC 619.

$3 \quad$ Canada

National Post v. Canada (2004) 236 DLR (4d) 551 (SCC).

$R v$ National Post (2010) 1 SCR 477 (SCC).

$4 \quad$ England and Wales

Ashworth Hospital Authority v MGN Ltd [2002] 1 WLR 2033 (HL).

Attorney General v Clough [1963] 1 QB 773.

Attorney-General v Mulholland [1963] 2 QB 477.

British Steel Corp v Granada Television [1981] AC 1096 (HL).

Camelot Group Plc v Centaur Communications Ltd [1999] QB 124 at 138 C-E.

D v National Society for Prevention of Cruelty to Children [1977] 2 WLR 201, [1977]

1 All ER 589 (HL).

Interbrew SA v Financial Times Ltd [2002] EWCA Civ 274, [2002] EMLR 24 (HL). 
Mersey Care NHS Trust v Ackroyd (No. 1) [2003] EWCA Civ 663, [2003] EMLR 36 (CA).

Saunders v Punch Limited [1998] 1WLR 986, [1998] 1 All ER 234 (Ch).

Xv Morgan Grampian [1991] 1 AC 1 (HL) at 44.

$5 \quad$ European Court of Human Rights

Financial Times Ltd v UK (2010) 50 EHRR 46 (Section IV, ECHR).

Goodwin v United Kingdom (1996) 22 EHRR 123 (Grand Chamber, ECHR).

Nagla v Latvia (73469/10) Fourth Section, ECHR 16 July 2013.

Nordisk Film \& TV A/S v Denmark (40485/02) First Section, ECHR 8 December 2005.

Observer and Guardian v the United Kingdom (13585/88) Court (Plenary), ECHR, 26 November 1991.

Sanoma Uitgevers BV v the Netherlands (38224/3) Grand Chamber, ECHR 14 September 2010.

$6 \quad$ United States of America

Branzburg v Hayes, 408 US 665 (1972).

re Special Proceedings 291 F Supp 2d 44 (DRI 2003)

B Legislation

$1 \quad$ New Zealand

Evidence Act 2006.

Evidence Amendment Act 1980 (No. 2).

2 Australia

Evidence Act 1906 (WA).

Evidence Act 1995 (Cth).

Evidence Act 1995 (NSW).

Evidence Act 2008 (Vic).

Evidence Act 2011 (ACT).

Evidence Amendment (Journalists' Privilege) Bill 2009 (Cth).

Evidence Amendment (Journalists’ Privilege) Bill 2010 (Cth).

Evidence Amendment (Journalists’ Privilege) Bill 2010 (Cth) (No. 2).

$3 \quad$ Canada

Canadian Charter of Rights and Freedoms, Part I of the Constitution Act 1982 (Canada Act 1982 (UK), sch B).

$4 \quad$ England and Wales

Contempt of Court Act 1981 (UK), s 10. 
Code of Criminal Procedure 2000 (Fr), s. 109.

Council of Europe Recommendation No. R (2000) 7 of the Committee of Ministers to member states on the right of journalists not to disclose their sources of information (Adopted by the Committee of Ministers on 8 March 2000, at the 701st meeting of the Ministers' Deputies).

European Convention on Human Rights (signed 4 November 1950, entered into force on 3 September 1953) art 10.

United Nations Declaration of Human Rights (signed in 1948, entered into force 16 December 1949), art 19.

$7 \quad$ Sweden

Freedom of the Press Act 1949 (Sweden), art. 3.

$8 \quad$ United States of America

Tenn. Code Ann. § 24-1-208 (Supp. 2000).

\section{Books and Chapter in Books}

David Banisar Silencing Sources: An International Survey of Protections and Threats to Journalists' Sources (Privacy International, London, 2008).

The Conscience of Europe: 50 Years of the European Court of Human Rights $\left(2^{\text {nd }}\right.$ Ed, Third Millennium Information, London, 2010).

Nicolee Dixon Shield Laws for Journalists (Queensland Parliamentary Library and Research Service, Research Brief No. 3, February 2012).

David Eady and ATH Smith Arlidge, Eady \& Smith on Contempt (4th ed, Sweet \& Maxwell, London, 2011).

David Feldman Civil Liberties and Human Rights in England and Wales (2nd ed, Oxford University Press, 2002).

Kathleen Ann Ruane Journalists' Privilege: Overview of the Law and Legislation in Recent Congresses ( $1^{\text {st }}$ Ed, Congressional Research Service, Washington D.C, 2011).

\section{Journal Articles}

Laurence B Alexander "Looking Out for the Watchdogs: A Legislative Proposal Limiting the Newsgathering Privilege to Journalists in the Greatest Need of Protection for Sources and Information" 20 Yale Law \& Pol. Rev. 97 (2002).

Vince Blasi “The Newsman’s Privilege: An Empirical Study” (1971-1972) 70 Mich L. Rev. 229.

Kelly Buchanan "Freedom of Expression and International Criminal Law: An Analysis of the Decision to Create a Testimonial Privilege for Journalists” (2004) 35 VUWLR 609.

Eoin Carolan "The Implications of Media Fragmentation and Contemporary Democratic Discourse for 'Journalistic Privilege' and the Protection of Sources” (2013) 49 Irish Jurist 182.

Ruth Costigan "Protection of Journalist's Sources” (2007) Public Law 464.

Monica Dias “Branzburg Revisted?” (2002) 26(1) News Media and the Law 4. 
Michael Douglas “A Broad Reading of WA’s Shield Laws” (2013) 18 MALR 377.

Randall D Elliason “The Problems with the Reporter's Privilege” 57 Am. U. Law. Rev. 1341 (2007-2008).

Anthony L Fargo "The Year of Leaking Dangerously: Shadowy Sources, Jailed Journalists and the Uncertain Future of the Federal Journalist’s Privilege” (2006) 14 Wm. \& Mary Bill Rts. J 1063.

Sara Phung "Function Not Form: Protecting Sources of Bloggers" (2012) 17 MALR 121.

Steven Price "Evidence about the chilling effect of ordering journalists to burn confidential sources (19 June 2009) Media Law Journal <www.medialawjournal.co.nz>.

Lori Robertson “Kind of Confidential” (2007) AJR June/July.

Devin M Smith “The Shields Pierce Easily: A Case for Fortifying the Journalists' Privilege in New Zealand" (2009) 18(1) Pacific Rim Law \& Policy Journal 217.

Matthew Tracey “Journalist Shield Laws in Australia” (2010) 29(2) Communications Law Bulletin 12.

Eileen M Wirth "The Impact of State Shield Laws on Investigative Reporting" (1 January, 1994). ETD collection for University of Nebraska - Lincoln < http://digitalcommons.unl.edu/dissertations >.

\section{E Parliamentary Materials and Court Briefs}

(25 October 2010) 3 AUSPD Cth HR 1242.

Law Commission Evidence Law: Privilege (NZLC PP23, 1994).

Kirsty Magarey Evidence Amendment (Journalists Privilege) Bill 2010 (No. 2) Parliament of Australia, Bills Digest No 39 2010-11, November 2010.

Julian Miles Amicus Curiae submission in Slater v Blomfeld CIV-2013-404-5218, 20 June 2014.

The Open Society Justice Initiative and others Amicus Curiae brief in Sanoma Uitgevers BV v the Netherlands, December 2009. 